\title{
What Determines Executives’ Remuneration in Malaysian Public Listed Companies?
}

\author{
Mazair Ghasemi \& Nazrul Hisyam Ab RazaK
}

\begin{abstract}
This paper examines the impact of executives'ownership, firm profitability, board size and its components, as well as some other financial factors, on executives' remuneration in the context of Malaysia. Using a sample of 2403 firmyears during 2006-2014 among listed companies in Bursa Malaysia, the findings show that firm profitability, leverage and number of non-executive directors have negative effects on executives' remuneration. Conversely, dividends, percentage of executives' directors, board size and size of firms have positive effects on executives 'remuneration. There is no evidence that executives' ownership has significant effects on their remuneration. From the viewpoint of the agency theory about the effects of larger boards, firm profitability, and executive percentage on executives' remuneration, it is perceived that the weak governance exists among listed companies in the Malaysian market. The insignificant impact of executives' ownership on their remuneration is an important finding of this research.
\end{abstract}

Keywords: Agency Theory; Bursa Malaysia; Board of directors; executive remuneration; executive ownership

\section{INTRODUCTION}

Recent financial crisis has raised serious criticisms, particularly regarding the role of corporate governance (CG) in determining executive remuneration (Bebchuk, Cohen, \& Spamann 2010; Fahlenbrach \& Stulz 2011; Kirkpatrick 2009). The enhancement of CG standards and disclosures has been at the forefront of international arguments in recent times, and the remuneration of executives and directors is one of the key issues in this debate. The main belief, derived from the principal-agent structure, is that, a well-designed remuneration contract helps to motivate executives to maximize shareholder wealth (Jensen \& Murphy 1990; Murphy 1999). Furthermore, executive remuneration is an important tool for both encouraging and retaining executives in a firm. The ideal executives' remuneration attempts to attract managers and incentivize them to develop growth opportunities, exert efforts, and minimize inefficient investments. The amelioration of CG standards and information disclosure has been at the forefront of worldwide debates in the recent times, and the remuneration of executives and directors is one of the main issues in these debates (Fahlenbrach \& Stulz 2011; Kirkpatrick 2009). In addition, family ownership and managerial ownership show an uncertainty in regard to the managers' remuneration (Vicknes 2003). Likewise, directors' payouts in GLCs have grown approximately $12 \%$ less compared to other companies. The results of a study by Kaur and Rahim (2007) showed the aggregate payout to directors in a sample of 639 firms that are listed in KLSE, is increased by $23 \%$ from RM1.3 billion to RM1.6 billion during a period of six years (2001 to 2006). Moreover, the executives' remuneration and its determinants have been relatively ignored in that study. In addition, Hamsawi (2011) indicated that the sum of the directors' payout in the top 20 firms was increased by $22 \%$ only in 2009 . Therefore, Executive remuneration is vigorously debated in Malaysia (Wooi \& Ming 2009). Hence, there were different remuneration policies among the listed companies in Malaysia that caused difficulty for applying executive remuneration as an instrument for reducing the agency conflict.

The insignificant or weak relationship between profitability and remuneration has been mentioned in some Malaysian studies (Nahar Abdullah 2006; Wooi \& Ming 2009). Although the issue of executives' remuneration has not been investigated in depth in the context of board components and managerial ownership.

Based on our study among previous research in developing markets, particularly in Malaysia, about factors which affects executives' remuneration, the studies which considered about role of executives, especially shareholding of company is very limited as well as effect of proportion of executives in directors board. However, while we know that various factors such as ownership structure, industry type, company life cycle stage and a number of other factors affect the level of executives' remuneration, this research focuses on the impact of executives on their remunerations. In order to understanding all aspects of executives' effects, we have considered the impact of executives' shareholding as well as proportion of executives on directors' board members as main aspects. Therefore, the finding of this study can be considered as contribution of our knowledge about role of executives in their remunerations in a developing market.

Based on agency theory, shareholders prefer that new project financed by lender because of external monitoring and better discipline of expenditure after receiving the loan 
by managers. In addition, when managers are shareholders, agency theory does not a clear argues about reaction of shareholders about leverage and also effect of that on executives' remuneration payment. The large amount of loans has led to a reduction in companies' ability to pay executives high remuneration, nonetheless; on the other hand, shareholders are encouraging executives to get more loans for new projects with higher remuneration. However, a previous study shows that in Malaysia there is no significant relationship between remuneration and the amount of loan received by firms (Amin, Kamarudin, Ismail, \& Sarman 2013). Therefore, the impact of financial leverage on managers' remuneration is not well understood. Therefore, in this research also test the leverage as an independent variable.

Based on agency theory shareholders also prefer receiving dividends to solve extra cash flow matter in the hand of managers and also signaling theory asserts that managers paying more dividend amount to show that they are confident about profit making by company in the future. Therefore, it can be assumed that shareholders if managers paying more dividends shareholders also compensate it with more remuneration. But if managers also are shareholders, then they are likely to behave according to entrenchment hypothesis and try to get more benefits for themselves. The key issue in relation to the dividend payout and the remuneration of executives is whether the dividend payment is resolved the agency conflict from shareholders' opinion or shareholders would prefer to pay more remuneration to align their interest with managers' interest? Therefore, the dividends also considered as another factor which affect remuneration in this study as independent variable.

Executives' Remuneration is broadly applied as an incentive that impacts strategies planned decisions made and by executives which cause great effect on companies' profitability (Ibrahim, Zin, Kassim \& Tamsir 2019). Based on classic corporate governance guidelines, firms should apply a good compensation policy to align the interest of managers with shareholders' benefits (Bebchuk \& Fried 2004; Council 2012). However in bursa Malaysia, as emerging market, some studies' findings demonstrate different results, such as; there is not significant relationship between present firm' profitability with executives' remuneration and only lagged profitability affects current remuneration (Jong 2018), in companies with Employee Shares Option Scheme (ESOS) and without ESOS plan there was not significant relationship between firms' performance (ROA) and executives' remuneration (Ghazali \& Taib 2015). Hence, the empirical studies showed different results from classic corporate governance expectation for relationship between firm profitability and compensation policy in Malaysian firms. This study tries to examine the effect of profitability on executive's rumination and considers this factor (firm's profitability) as independent variable.
Basically, the directors' board members have two main roles, monitoring and advising roles (Carter, Simkins, \& Simpson 2003), when the number of executives on the board increased and the indecency of the boards is reduced, executive directors significantly push BOD to increase their remuneration on the pretext of both monitoring and decision-making of their responsibility roles. Under other conditions, the bargaining power of executives are decreased if the number of non-executive directors are increased and the lower level of remuneration for executives are expected. However, In Malaysian context, studies assert different impact of board members' independence on executives' remuneration. For instance Yatim (2013) shows positive effect of non-executive board members on executives' remuneration but the research by Malak (2015) shows negative effect. However Jong and Ho (2019) claims there is not significant relationship between number of independence directors and executives' remuneration in public listed companies in Malaysia.

Since managing a bigger size firm needs more experience, knowledge, and management skills compare to a smaller one, therefore size of company can be assumed as a fundamental factor of executives' remuneration and in this research also used as control variable. to control the effect of size of business, which is one of most important reason of amount of remuneration, we use it as control variable in the model. In addition, board size also mentioned as important factor which affects directors' remuneration and used as control variable in this research. other variables considered as independent variables.

This exploratory research uses panel data, and the analysis is conducted by using random regression model or fixed regression model based on the Hausman Test. This study tries to examine different proxies or measures for independent and control variables to make sure that findings are consistent; hence two regressions are examined due to testing different proxies. Results indicate that executives' ownership has insignificant effects on executives' remuneration and it may infer as an enhancement in governance, but from negative effects of profitability as well as positive effects of board size on executive remuneration, it can be concluded that there is a weak contractual agreement and also lack of supervision when number of executives are increased or board size becomes larger than the previous size. The insignificant effect of executives' ownership on executives' remuneration shows that the entrenchment hypothesis which asserts that managers with higher percentage of ownership have more power and can use this power to extract more benefit for themselves at least from remuneration viewpoint is not accepted in Malaysian market.

The article is organized as follows: Section two presents a brief review of determinants of executive remuneration. Section three describes the data, research methodology, and different proxies of variables. Section four provides the empirical results and analysis. Section 
five provides concluding remarks and some suggestions for further studies.

\section{LITERATURE REVIEW}

\section{AGENCY THEORY}

Agency theory discusses interest conflicts in firms based on separation of owners and agents/managers and emphasize that some monitoring instruments or incentive approaches reduce this problem (Hill \& Jones 1992). However, scholars named mentioned problem as type 1 of agency problem (Principal-Agent Problem) (Jiraporn, Miller, Yoon, \& Kim 2008; Ratnawati, Abdul-Hamid, \& Popoola 2016). Other scholars developed agency theory based on interest conflict between majority shareholders and minority shareholders as type 2 of agency problem (Principal-Principal Problem) (Lim \& Yen 2017; Nurim, Sunardi, \& Raharti 2017) and also between shareholders and creditors as type 3 of agency problem (PrincipalCreditor Problem) (El-Jor 2017; Panda \& Leepsa 2017). The agency matter between the agent and principal in the companies has specific causes, however, several explanations for the occurrence of the this problem like ownership separates from firms' control, differences attitudes about risk between agents and principal, involving agents a short time duration involvement of agents in the organization, occurrence of information asymmetry between managers and shareholders and insufficient incentive plans for the agents mentioned as main reasons of Principal-Agent Problem (Chowdhury 2012). Agency cost is one of the internal costs attached with the managers that happen because of the misalignment of the interest between the principal and agent. An inadequate remuneration package may cause managers use property of owners for their benefit. However, a good plan for compensating managers can motivate them to effort harder for the better performance of the company and it led to wealth maximization of owners (Elsayed \& Elbardan 2018).

Managerial ownership is a well-known solution to the principal-agent problem (McKnight \& Weir 2009; Singh \& Davidson 2003). However, researchers have also found that high level of executives' ownership can reduce the company value based on managerial entrenchment, thus external shareholders find it hard to monitor and control the actions of this kind of executives (DeAngelo \& DeAngelo 1985; Stulz 1988), and executives could divert the outside investors' benefits to themselves (Benson \& Davidson 2010; Jeelinek \& Stuerke 2009). The Agency theory argues that managers are self-serving and governance mechanisms, including the executive compensation structure, help to align the incentives of top managers with the interests of shareholders (Jensen \& Meckling 1976). Thus, executive compensation is an important tool in both motivating and retaining firm executives.
Studies in developed countries have shown that ownership structure is one of the determinants of executive remuneration. Intuitively, it is stated that managers can determine their own remuneration packages if they have some ownership in the firm. Some studies showed positive relations (Allen 1981; Holderness \& Sheehan 1988; Werner, Tosi \& Gomez-Mejia 2005) and some of them indicated negative relations (Attaway 2000; McConaughy 2000).

\section{FINANCIAL PROFITABILITY}

From an agency theory viewpoint, the link between firm profitability and executives' pay should provide a fundamental incentive mechanism for corporate achievement. In other words, ownership and remuneration mechanisms may substitute one another (Aggarwal \& Samwick 1999; Conyon, Core, \& Guay 2010; Fernandes, Ferreira, Matos, \& Murphy 2013; Mat Nor \& Sulong 2007; Mehran 1995; Ozkan 2007). On the other hand, some scholars reported rent extraction through over remuneration by managers (Salim \& Wan-Hussin 2009).

However, Malaysian scholars approve different results due to the relationship between remuneration and firm profitability. For instance, Dogan and Smyth (2002) found a positive relationship between board remuneration and sales turnover using a sample of Malaysian companies listed on Kuala Lumpur Stock Exchange (KLSE) from 1989 to 2000. Hassan, Christopher, and Evans (2003) investigated Malaysian firms pre and during financial crisis in Asia (1996 to 1998), reported the weak positive relationship between director remuneration and profitability. They claimed that the remuneration was less successful to improve firm profitability when used in family companies, because interest conflict was existent between minority and majority shareholders. Ibrahim, Ibrahim, Ismal, Adibah, and Kamarudin (2005) defined new evidence on the relationship between firm profitability and directors' remuneration in Malaysia, showing evidence of good governance and appraisal system of Malaysian firms, particularly in deciding the directors' remuneration. Also Abdullah (2006) reported no linkage between executives' remuneration to return on assets (ROA). Jaafar, Wahab, and James (2012) examined a panel of 537 firms from 2007 and 2009 in Malaysia family firms to answer the relationship between director remuneration and profitability. They reported the remuneration driven board incentive for improving profitability. Furthermore, they do not find any evidence that the family firm manipulated a power and control for personal wealth. Therefore, family members do not manipulate their positions of power on boards of directors and as majority shareholders to increase remuneration for personal benefits. Therefore, when examined in a multivariate setting, the positive significance disappears. According to the agency theory, there is a positive link between firm profitability and managers' remuneration (Mengistae and Colin Xu, 2004); hence, this study hypothesizes the following: 
Hypothesis 1: There is a positive effect of financial profitability on executives' remuneration.

\section{Executives' Ownership}

Agency Theory predicts a negative relationship between managerial ownership and managerial remuneration since alignment between shareholders and executives is an increasing function of managerial ownership (Jensen \& Meckling 1976). Dogan and Smyth (2002) report that board of directors' remuneration are associated with sales earnings in a positive way but negatively related to the ownership concentration for Malaysian listed companies over a period of 12 years. Alternatively, some scholars revealed that high level of ownership concentration may allow managers to impose highly contingent remuneration contracts on executives, leading to a positive relationship between managerial ownership and managerial remuneration (Allen 1981; Cheung, Stouraitis, \& Wong 2005; Holderness \& Sheehan 1988; Werner et al. 2005). That is to say, managerial ownership instrument and remuneration mechanism can complement each other. For instance, Lee and Chen (2011) explain that remuneration and ownership of Chief Executive Officer (CEO) are interdependent and the ownership of CEO is positively associated with remuneration. However, Yatim (2013) reported that there is no relationship between insider ownership and directors' remuneration of 428 listed firms on the Bursa Malaysia for the financial year ending 2008. However, two different opinions exist about the agency dilemma between managerial ownership and managerial remuneration. The Convergence-Of-Interest Hypothesis posits that increasing share ownership by managers will increase their interest aligned with the shareholders (Ang, Cole, \& Lin 2000; Fleming, Heaney \& McCosker 2005), hence there is no need to pay more compensation (Conyon et al. 2010; Fernandes et al. 2013). Although entrenchment hypothesis argues that owner-managers have more influence on deriving more remuneration from firms without considering their performance (Allen 1981; Holderness \& Sheehan 1988; Werner et al. 2005). Overall, the impact of ownership structure on executive pay is unclear given the mixed nature of the empirical results. The owner managed companies are widespread among Malaysian firms (Mat Nor \& Sulong 2007; Vethanayagam, Yahya \& Haron 2006). Considering entrenched managers, based on the high level of ownership, concentrated managerial ownership results in weak corporate governance system in Malaysia (Zulkarnain 2007). Hence, Hypothesis 2 is stated as follows:

Hypothesis 2: There is a positive effect of executives' ownership on executives' remuneration.

\section{Executive Directors}

Finkelstein and D'aveni (1994) implied that a separate structure of management leads to a superior level of independence to the board of directors (BOD) in various subjects associated with monitoring managerial profitability. They also argued that if the managers serve as members on the BOD, the independency of the BOD is reduced and it may influence the design of the remuneration contract (Core, Holthausen, \& Larcker 1999). Iyengar, Williams, and Zampelli (2005) also confirmed this prediction, meaning that they found that remuneration levels are higher in companies where the executive is also a member of the board. In contrast, Angbazo and Narayanan (1997) and Conyon (1997) found no such relation in their pieces of research of the US and British companies, respectively. Moreover, Banghøj, Gabrielsen, Petersen, and Plenborg (2010) examined the relationship between CG characteristics and executive remuneration. Their results showed that there is no significant effect of inside board members on executive remuneration in the privately held firms in Denmark. In addition, it seems that when executives are on the board, their bargaining power about remuneration is higher, and shareholders are also trying to satisfy them by paying more because of both roles of company's activities decision making and also monitoring role.

Hypothesis 3: There is a positive association between the proportion of executive directors on boards and executives' remuneration.

\section{Non-executive Directors}

Agency literature argues the domination of non-executives on board of directors provides effective monitoring and controlling of firm activities in reducing opportunistic managerial behaviors and expropriation of a firm's resources (Fama \& Jensen 1983). Non-executives also contribute a noteworthy set of resources and bring experience to the company (Goh \& Gupta 2016). Nonexecutives also play a significant role in designing effective remuneration contract. Therefore, executives and top managers have an incentive to serve in the best interest of shareholders (Fama \& Jensen 1983). Overly, Nonexecutive directors lower down the operational cost of maintaining the board of directors (basic salary, bonus, allowances and perks). This is because an independent non executive director is only entitled to receive fees (Wooi \& Ming 2009). In addition, a proactive board dominated by non executive directors, according to Pearce and Zahra (1991) deliver an effective corporate governance performance against self-serving executive directors. Thus, in accordance to international corporate governance best practices by Cadbury (1992) and Remuneration and Greenbury (1995), non-executives are supposed to have negative effects on managerial remuneration. Since the main role of independent directors is supervisory role and they do not have executive responsibility, therefore, shareholders do not have a reason to pay high remuneration. Therefore, the following hypothesis is assumed:

Hypothesis 4: The executives' remuneration is negatively related to the proportion of non-executive directors on boards.

\section{Dividends}

Over the years of the Modern Corporation, methods and procedures of managerial payment have changed 
considerably to align the interest of shareholders and managers. Because dividend payment reduces free cash flow, and this reduction reduces the probability of managers misusing the company's resources, thereby reducing the dividends ultimately reducing the conflict between managers and shareholders. Therefore, Dividends are an effective instrument for mitigating the agency problem, hence well-organized executive remuneration packages should be planned to reward fitting levels of dividend payout. On other hand, if remuneration scheme achieves to align Managers (agent) and shareholders (owner), then payout amount as a substitute alternatives of agency solution will be relaxed (Fama \& Jensen 1983). Otherwise dividends may be used as a complement method to reduce agent problems. Kahle and Kathleen (2002) suggest that amendments in remuneration schemes have caused changes in firms' payout policies. This means that if remuneration scheme achieves to align managers and shareholders interest, then the role of dividends as a substitute alternative is mitigated. The study by Bhattacharyya, Mawani, and Morrill (2008) indicates that executive remuneration is negatively associated with dividend payout. Otherwise, dividends may be used as a complement method to reduce the agent problem. In line with this notions, some scholars assigned a positive linkage between executive remuneration and dividend payment (Healy 1985; Lewellen, Loderer, \& Martin 1987). Bao (2013) also reports that executive wage has a positive impact on corporate cash dividends. In other words, shareholders can make payments to their directors in order to match their interests or, if paid dividends too much, their interests are secured and do not require to pay excessive remuneration. This gives rise to the following hypothesis:

Hypothesis 5: There is a positive effect of Dividends on executives' remuneration.

\section{Leverage}

When explaining the agency theory, (Jensen \& Meckling 1976) assumes that managers are risk averse. Therefore, managers that manage firms with higher risk should get higher remuneration than managers who manage firms with lower risk. However, the higher debt leads to less ability of firms to pay more amounts of remuneration. Amin et al. (2013) studied directors' remuneration in Malaysia by using 845 firms data from year 2009 to 2011. They showed that when the heteroskedasticity problem was solved, the leverage has significant positive effects on directors' remuneration. But when industry and year effect were controlled, there was insignificant relationships between them. Cheah, Lim, and Yen (2012) studied remuneration received by executive directors of 191 listed Malaysian companies from 2002 to 2007 and found that the bulk of their remuneration was fixed in nature. Indeed, salaries made up $75 \%$ of the directors' total remunerations. In addition, dividends received by directors through their share's ownership represented another main source of their earnings. The final hypothesis is therefore stated as follows:
The high amount of loan leads to

Hypothesis 6: There is a negative effect of leverage on executives' remuneration.

\section{Firm Size (Different size of firm different remuneration packages)}

The executives of large firms are paid more than those in small firms due to task complexity, financial matters, and the difficulty of decision-making (Jensen \& Murphy 1990). Previous empirical studies generally found a strong positive relationship between firm size and executive pay (Sridharan 1996; Ueng, Wells \& Lilly 2000). The research done by Laing and Weir (1999) on 125 largest public listed companies in UK found that company size is a key determinant of pay. The link between top executive pay and company size was justifiable given that larger organizations carried greater responsibilities which would be translated to a higher pay (Zhou 2000). In Malaysia, Abdullah (2006) found firm size to be the important factor influencing board remuneration. Another evidence from Malaysia shows that directors in big firms usually earn more than directors in small firms (Ibrahim et al. 2005). Consistent with previous Malaysian studies, Jaafar and James (2013) found a positive effect of firm size on executives' remuneration based on the study of 537 firms listed in Bursa Malaysia during 2007 to 2009. Hence, in terms of firm size, increasing in responsibility should be compensated with a higher remuneration package. In fact, in a company with a large size directors' board have more responsibility, experience, knowledge and time to monitor its activities, since with more remuneration should compensate their efforts. Thus, in this study firm size is applied as control variable.

\section{Board Size}

The Agency theory suggests a number of mechanisms to alleviate agency problems about the quality of monitoring the managers 'activities (Miller 2002). The main core of its mechanisms is related to the directors' board such as; smaller boards and greater board independence. Prior studies show that larger directors' board is associated with ineffective monitoring (Conyon \& Peck 1998; Yermack 1996). More recently, Yatim (2013) documents a positive and significant association between directors' remuneration and board size among 428 listed companies on the Bursa Malaysia for the financial year ending 2008. He argued that larger boards hinder board effectiveness. This result is consistent with the suggestion that the larger boards are easily controlled by CEO (Croci, Gonenc \& Ozkan 2012). If enlarged board size causes reduction on the effective monitoring, executives' remuneration is expected to be positively associated with the number of directors on the board. Paying executives more remuneration will inevitably happen because of executives influence on decision-making more than other directors as well as the weaknesses of independent directors in the board. Hence, the board size is used as control variable in this research. 


\section{ReSEARCH Methodology}

\section{DATA AND SAMPLE}

Data on the remuneration of executives and other corporate governance data of Malaysian companies are not available in any regular database. Therefore, they must be extracted directly from the annual reports of companies. The annual reports of 267 firms for the period 2006-2014 were acquired from Bursa Malaysia Website. Data on executives' remuneration and executives' shareholding, along with its different components, are reported in the Statement on Corporate Governance and Analysis of Shareholdings sections of the Notes to the Financial Statements. In addition, data on board size, number of executives, and number of non-executives are collected from the Profile of Board of Directors section of Annual reports. Other financial data are extracted from DataStream by Thomson Reuter. It should be noted that executives' remuneration is measured by fees, salary, bonuses and benefit of kin. If total members of the board were non-executives or the percentage of executives' shareholdings were continuously zero for the years from 2006 to 2014, then these kinds of companies are excluded from sample. Since the new governmental rules and regulations lead to changing listed companies' decisions, it could be expected that companies' behaviors were changed after "new Companies Act 2016" and "corporate governance reform in 2017". Therefore, authors of this study focus on the firms' behavior before new reforms, in future, this study can be done again with new data (after year 2016) and compare their results.

\section{VARIABLES AND PROXIES}

Variables used for the analysis include executives' remuneration, financial profitability, leverage, dividends, number of non-executives, number of executives, size of board, and firm size. Table 1 shows the variables and their proxies that are used in both models. In addition, some other scholars who applied mentioned proxies in their studies are introduced.

MODEL

Because the sample comprises a heterogeneous set of nonfinancial firms belonging to divers sectors of activity that are listed on the Main Market of Bursa Malaysia, it is rational to assume that individual companies may have their own characteristics that distinguish them from the others. In addition, their changes across time justify a panel data regression model. Considering the theoretical framework, three estimators of executives' remuneration are specified: pooled ordinary least squares (OLS); fixed effects; and random effects. With respect to the most important determinants of executive's remuneration based on the results on previous research on corporate governance and directors' remuneration, the following two models are formulated to state the hypothesized relationship:

$$
\begin{aligned}
& \text { Executives' Remuneration }{ }_{i t} \\
& \begin{array}{l}
=\beta_{0}+\beta_{1} \text { Executives' ownership }_{i t}+\beta_{2} R O E_{i t}+\beta_{3} \frac{\text { Debt }_{\text {Equity }}}{\text { it }}+\beta_{4} \operatorname{Ln}(\text { Dividends })_{\text {it }} \\
+\beta_{5} \text { Non_Executives }_{\text {it }}+\beta_{6} \text { Total Directors }_{\text {it }}+\beta_{7} \operatorname{Ln}(\text { Asset })_{\text {it }}+\varepsilon_{i t}
\end{array} \\
& \text { Executives' Remuneration }{ }_{i t}
\end{aligned}
$$

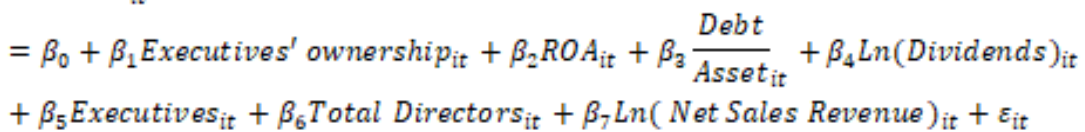

\begin{tabular}{|c|c|}
\hline Variable & Proxy and measurement \\
\hline \multicolumn{2}{|l|}{ Dependent } \\
\hline Executives' Remuneration & Ln (Executives' Remuneration) (Jaafar \& James 2014; Wooi \& Ming 2009) \\
\hline Independent \& Control & $\begin{array}{l}\text { Executives' ownership/ Outstanding Shares (extracted from annual report of companies) } \\
\text { (Executives' ownership) (Saleh, Iskandar \& Rahmat 2005; Taufil-Mohd, Md-Rus \& Musallam } \\
\text { 2013) }\end{array}$ \\
\hline \multirow[t]{2}{*}{ Executives' ownership } & $\begin{array}{l}\text { Return on Equity }(R O E) \text { (Ismail, Yabai \& Hahn 2014) } \\
\text { Return on Asset (ROA) (Ntim, Lindop, Osei \& Thomas 2013) }\end{array}$ \\
\hline & $\begin{array}{ll}\text { Debt/Asset } & \text { (Ahmad \& Aris 2015) } \\
\text { Debt/Equity } & \text { (Appannan \& Sim 2011) }\end{array}$ \\
\hline Financial profitability & Natural Logarithm of total dividend payment (Ln (Dividend)) (Ahmad \& Aris 2015) \\
\hline Leverage & The total number of Non-executives Directors (Non_executives) (Yatim 2013) \\
\hline Dividends & The total number of executives (Executives) (Jaafar \& James 2013) \\
\hline Non-Executives & The total number of directors (Total Directors) (Amin, Kamarudin \& Ismail 2014) \\
\hline Executives & $\begin{array}{l}\text { Natural Logarithm of Total Asset (Ln(Assets)) (Ahmad \& Aris 2015) } \\
\text { Natural Logarithm of sales Revenue (Ln(Net Sales Revenue)) (Uyar 2009) }\end{array}$ \\
\hline
\end{tabular}

TABLE 1. Variables, proxies and measurements 
Two models are used in this study, because of testing different measures and proxies to gain a better understanding of the factors' effect on remuneration to ensure the robustness of the models. For instance, performance and debt have considered in the model 1 based on equity and in models 2 based on asset. In addition, firm's size is tested based on total asset and sales revenue as different proxies. In model 1 number of nonexecutives' effect on remuneration is tested and in model 2 executives' effect on remuneration is studied. Finally, with comparing the results of these two models help us to have better understanding about mentioned we want to test different measure for profitability and different proxies for firm's size.

Return on owner's equity (ROE) ratio measures the shareholders rate of return on their investment in the company. Return on assets (ROA) ratio measures for the operating efficiency for the company based on the firm's generated profits from its total assets. ROE (ROA) represents short-term financial performance of a firm by measuring how a firm efficiently creates profits using its equity (assets) during a fiscal year (Kang, Lee, \& Huh 2010). Although these two ratios show a different coefficient with CEO compensation (Lin \& Lin 2014) and directors' remuneration (Jaafar, Nawawi, Salin \& Azlin 2014) therefore scholars preferred to test both them in their research because shareholders have different viewpoints to use one of them for compensate the CEO or managers efforts.

\section{ANALYSIS OF RESULtS}

Table 2 presents the descriptive statistics. The sample mean of the total executives' remuneration were RM2.56 million $(\ln ($ executives remuneration $)=14.09)$ during years 2006 to 2014. Regarding to executives' remuneration, the average that is reported by Jaafar, James and Wahab (2012) was RM1.98 million for 2007 to 2009. In addition, Yatim (2013) reported RM2.54 million as executives' remuneration for the financial year ending 2008. The average number of board members ranges from 4 to 13 with an average of 7.7 members. The board composition included the averages of 4.76 Non-executive and 2.95 Executives members. Regarding to board characters, Yatim (2013) reported average 7.58 members for board size. In addition, Johl, Kaur and Cooper (2015) reported 7.44 members for the board average and the average of independent directors was 43.6 percent based on a study of the 700 public listed firms in Malaysia for the year 2009. As presented by table 4 , the average of firm's shares percentage owned by executives were $10.24 \%$ with the lowest of $0 \%$ and highest of $74.4 \%$. In this respect, Abdullah, Ismail, and Jamaluddin (2016) showed $8.77 \%$ as an Executive directors' ownership and Yatim (2013) reported $11.18 \%$ as an insider ownership. The independent financial variables denoted by Debt/Asset, Debt/Equity, ROA, ROE, Ln (Dividends), Ln (Asset), and Ln (Net Asset Revenue) have mean values of 17\%, 41\%, $8.3 \%, 10.07 \%, 8.33,13.08$, and 12.65 , respectively.

Figure 1 plots the annual frequency of executives' remuneration amounts from 2006 to 2014 . Firms generally tended to increase remuneration amounts from 2006 to 2014. The executives' remuneration amounts only experienced constant level of payments in 2010 compared to the previous year. This leverage stability was mentioned in several previous studies. If year 2006 assumed as a base year then it can be concluded that executive's remuneration increases $98 \%$ during these nine years.

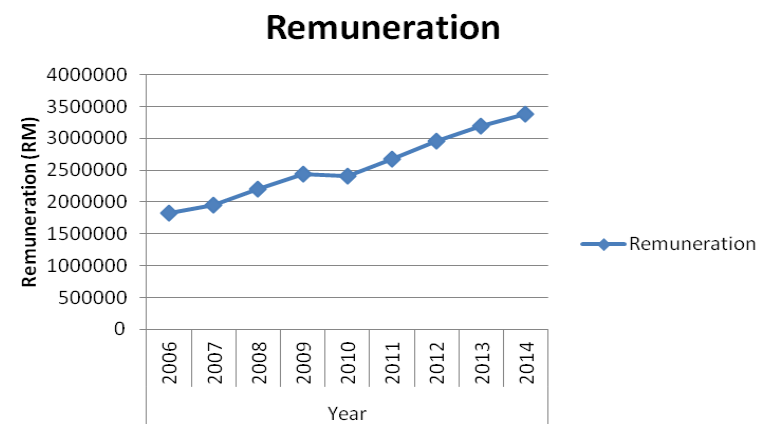

FIGURE 1. Executives' remuneration Trends from 2006 to 2014

\section{MULTICOLLINEARITY TEST}

The calculation of the VIF (variance inflation factor) is a formal technique to detect multicollinearity (Gurajati, 2003). Multicollinearity would not be a matter if the value

TABLE 2. Descriptive Statistics

\begin{tabular}{|c|c|c|c|c|c|c|}
\hline Variable & Debt/Equity & Debt/Asset & ROE & ROA & Ln (Div) & Ln (Asset) \\
\hline Mean & 0.41 & 0.17 & 10.07 & 8.30 & 8.33 & 13.08 \\
\hline Maximum & 4.04 & 0.60 & 77 & 40 & 14.30 & 18.08 \\
\hline Minimum & 0 & 0 & -40 & -20 & 0 & 10 \\
\hline Std. Dev. & 0.51 & .15 & 9.36 & 6.66 & 2.79 & 1.27 \\
\hline Variable & $\begin{array}{l}\text { Ln (Net Sales } \\
\text { Revenue) }\end{array}$ & $\begin{array}{l}\text { Ln (Executive } \\
\text { Remuneration) }\end{array}$ & $\begin{array}{c}\text { No. of } \\
\text { Executives }\end{array}$ & $\begin{array}{c}\text { No. of } \\
\text { Non-Executives }\end{array}$ & $\begin{array}{c}\text { Percentage of Executives } \\
\text { shareholdings }\end{array}$ & $\begin{array}{c}\text { Total No. of } \\
\text { Board Members }\end{array}$ \\
\hline Mean & 12.65 & 14.09 & 2.95 & 4.76 & 10.24 & 7.70 \\
\hline Maximum & 16.82 & 17.90 & 7 & 11 & 74.46 & 13 \\
\hline Minimum & 8.65 & 0 & 0 & 2 & 0 & 4 \\
\hline Std. Dev. & 1.32 & 2.03 & 1.48 & 1.61 & 14.38 & 1.81 \\
\hline
\end{tabular}


TABLE 3. Collinearity Statistics of Independent Variables

\begin{tabular}{|c|c|c|c|c|c|}
\hline \multicolumn{3}{|c|}{ Model 1} & \multicolumn{3}{|c|}{ Model 2} \\
\hline Variable & VIF & $1 / \mathrm{VIF}$ & Variable & VIF & $1 / \mathrm{VIF}$ \\
\hline Ln(asset) & 1.82 & 0.54 & Ln(net sales Revenue) & 1.78 & 0.56 \\
\hline Non-executives & 1.80 & 0.55 & Executives & 1.14 & 0.87 \\
\hline Board size & 1.66 & 0.60 & Board size & 1.12 & 0.89 \\
\hline Ln(dividends) & 1.61 & 0.62 & Ln(dividends) & 1.42 & 0.70 \\
\hline Debt/Equity & 1.27 & 0.78 & Debt/Asset & 1.53 & 0.65 \\
\hline Executives' ownership & 1.15 & 0.86 & Executives' ownership & 1.15 & 0.86 \\
\hline ROE & 1.14 & 0.88 & ROA & 1.25 & 0.80 \\
\hline Mean VIF & \multicolumn{2}{|c|}{1.49} & Mean VIF & \multicolumn{2}{|c|}{1.34} \\
\hline
\end{tabular}

of VIF is less than 10 and the tolerance value of each variable is more than 0.10 (Neter, Wasserman \& Kutner 1983). Table 3 shows that VIF for all the independent variables of both models are significantly below 10 , which indicate that multicollinearity is not a problem. The VIF results are generated by STATA 13 .

\section{Tests of Panel Data Regressions}

Table 4 shows the results of Breusch and Pagan Lagrangian Multiplier Test to choose between pooled or random effects. The result of chi-square in Table 6 indicates that for both models, the random effect model is more suitable compared to the pooled estimator.

TABLE 4. Breusch and Pagan Lagrangian Multiplier Test

\begin{tabular}{ccc}
\hline & Model 1 & Model 2 \\
\hline Chi2 & 8142.28 & 8045.54 \\
Prob. & 0.0000 & 0.0000 \\
\hline
\end{tabular}

Hausman Test is used to select between the random and fixed effects (Verbeek 2008). Table 5 presents the results of the Hausman Test, which shows that the fixed effect is an appropriate method for the both models.

TABLE 5. Hausman Test

\begin{tabular}{ccc}
\hline & Model 1 & Model 2 \\
\hline Chi2 & 26.44 & 21.22 \\
Prob. & 0.0004 & 0.0002 \\
Fixed & $\square$ & $\square$ \\
Random & & \\
\hline
\end{tabular}

\section{Autocorrelation and Heteroscedasticity Tests}

In this step, two tests should be done to understand whether these two regression models have heteroscedasticity and serial correlation problems. Table 6 presents the results of the Modified Wald Test for group-wise heteroscedasticity in the fixed effects regression. Table 6 shows that the null hypothesis of "there is no heteroscedasticity" could comfortably reject these models. According to the Wooldridge Test, Table 7 indicates that the null hypotheses (H0: no first-order autocorrelation) are rejected for the two models. Since these two models have serial correlation and heteroskedasticity problems, hence, the robust standard errors should be run to reach reliable results.

TABLE 6. Modified Wald Test (Heteroscedasticity)

\begin{tabular}{ccc}
\hline & Model 1 & Model 2 \\
\hline Chi2 & $5.9 \mathrm{e}+06$ & $2.6 \mathrm{e}+06$ \\
Prob. & 0.0000 & 0.0000 \\
Heteroscedasticity & $\square$ & $\square$ \\
\hline
\end{tabular}

TABLE 7. Wooldridge Test (Serial Correlation)

\begin{tabular}{ccc}
\hline & Model 1 & Model 2 \\
\hline F & 54.733 & 77.093 \\
Prob. & 0.0000 & 0.0000 \\
Serial correlation & $\square$ & $\square$ \\
\hline
\end{tabular}

\section{Models Results}

Table 8 presents the results of this study. In contrast to the prediction of Hypothesis 1, this study finds an insignificant relationship between executives' remuneration and financial profitability. This finding is in line with the results of Abdullah (2006) study. It can be mentioned that both proxies ROA and ROE have no significant relationship with executives' remuneration. According to the Agency Theory, owners can mitigate the agency conflict by designing a good contract between managers and shareholders, which leads to align their interest. Therefore, if changes of profitability do not affect executives' remuneration, it can be concluded that there was a weak contractual agreement in the Malaysian Market. Both regression results in Table 8 show that executives' shareholdings have no significant effect on executives' remuneration; hence, hypothesis 2 is not supported. This finding does not support the opinion 
TABLE 8. Estimation Results

\begin{tabular}{cccc}
\hline Model 1 & \multicolumn{3}{c}{ Model 2 } \\
\hline Executives' ownership & $.0010(.0033)$ & Executives' ownership & $.0026(.0034)$ \\
ROE & $-.0027(.0039)$ & ROA & $-.0110(.0077)$ \\
Debt/Equity & $-.2161(.0507)^{* * *}$ & Debt/Asset & $-.3088(.1736)^{* * *}$ \\
Ln(Dividends) & $.0102(.0056)^{*}$ & Ln( Dividends) & $.0190(.0060)^{* * *}$ \\
Non-executives & $-.1547(.0534)^{* * *}$ & Executives & $.9028(.3270)^{* * *}$ \\
Total directors & $.1813(.0418)^{* * *}$ & Total directors & $.0738(.0212)^{* * *}$ \\
Ln(asset) & $.6276(.0599)^{* * *}$ & Ln (net sale revenue) & $.4284(.0632)^{* * *}$ \\
cons & $5.2415(.8152)^{* * *}$ & cons & $7.7257(.8284)^{* * *}$ \\
Number of obs. & 2372 & Number of obs. & 2372 \\
F (7,266) & 267 & & 267 \\
Prob $>$ F & 24.00 & $\mathrm{~F}(7,266)$ & 23.72 \\
R- squared (Overall) & 0.0000 & Prob $>\mathrm{F}$ & 0.0000 \\
\hline
\end{tabular}

Notes: Robust standard errors are presented in parentheses. $* * *$ Indicates the statistical significance at $1 \%$. $* *$ Indicates the statistical significance at 5\%. Indicates the statistical significance at $10 \%$.

that level of executive's ownership provides a better opportunity for managers to rent extraction through overremuneration (Salim \& Wan-Hussin 2009). In line with Hypothesis 3, the results in Table 8 present a positive association between board size and executives' remuneration on both models (coefficient $=0.1813 \& 0.0738 ; \mathrm{p}<0.01$ ). According to the Agency Theory, larger boards hinder board effectiveness (Yatim 2013). This may lead to higher remuneration for executives as larger boards are easily controlled by CEOs (Core et al., 1999). As predicted by Hypothesis 4, the proportion of executive directors on the board has positive effects on executives' remuneration. This finding of Model 2 (coefficient $=0.9028 ; p<0.01$ ) shows that more executives on the board leads to specify more remuneration. In addition, the finding of Model 1 is consistent with the Hypothesis 5. That is, if the proportion of non-executives becomes larger, then the executives' remuneration decreases (coefficient $=-.1574 ; \mathrm{p}<0.01$ ).

These findings show that non-executive directors act based on the monitoring role. However, when the proportion of executive directors enhance in the board, then it can decrease the independency of the board and board members are less sensitive to the managers' remuneration. The negative effect of non-executives on executives' remuneration is in line with the results of Yatim (2013) in the Malaysian market. Recall that Hypothesis 6 predicts that dividends are positively related to executives' remuneration. In line with Hypothesis 6, the study finds a positive association between dividends and executives' remuneration (coefficient of model $1=.0102 ; \mathrm{p}<0.1$, coefficient of model $2=0.0190 ; \mathrm{p}<0.01)$. In fact, shareholders pay more remuneration to compensate managers for high level of pay out. To be precise, changes in the firms' pay out policies have caused amendments in remuneration schemes. The study also finds support for Hypothesis 7, which predicts that executives' remuneration is negatively associated with the leverage. (Coefficient of model $1=-.2161 ; \mathrm{p}<0.01$, coefficient of model $2=-.3088$; $\mathrm{p}<0.1$ ). This finding is in line with results of the study by Jaafar and James (2013) in Malaysian public listed companies. The negative relationship between these two variables is likely due to the agency theory perspective that suggests debt and remuneration as substitute instruments for reducing conflicts between managers and shareholders. Finally, consistent with the prediction of Hypothesis 8, this study finds a strong positive relationship (Coefficient of model $1=0.6276 ; \mathrm{p}<0.01$, coefficient of model $2=.4284$; $\mathrm{p}<0.01$ ) between firm size and executives' remuneration based on both models. According to both firm size proxies Ln (Asset) \& Ln (Net Sales Revenue), it can be concluded that managing large type companies, either on asset size or sales scale, leads to more managerial remuneration. This finding is consistent with most of the previous studies (Ibrahim et al. 2005; Jaafar \& James 2013; Yatim 2013).

\section{Conclusion AND Discussion}

This study attempts to examine factors that are associated with the level of executives' remuneration in public listed companies with a focus on board components. The issue of executives' remuneration has not been studied in depth in the Malaysian market, as a developing country, where good governance practices are still evolving in listed companies in Bursa Malaysia. Indeed, most literature has been concerned with the directors' remuneration in developed economies but this study not only was carried out in Malaysia as a developing country, but also focuses on executive remuneration as the most important part of directors' remuneration. The methodology of the panel data models is applied to investigate whether executive's ownership, financial profitability, leverage, firm size, board 
size and board members composition have significant relationship with executives' remuneration. The present study reveals the following findings.

The research contributes to the growing literature on executives' remuneration and it provides evidence on the attempts of governance reforms in recent years in influencing board members' remuneration. The present study reveals the following findings. Executives' Remuneration is positively related to dividends, board size, firm size (both proxies; Ln (Asset) and Ln (net sales revenue), and proportion of executive directors. In contrast, leverage and proportion of non-executives directors have negative effect on executives' directors. However, both models show that financial profitability (both ROA and ROE) and executives' ownership have not significant relationship with executives' remuneration.

Although this study makes some contribution to the corporate governance and remuneration debate, some limitations of this study should be mentioned to extend this study in future research. First, the potential limitations of using the total fees, salary, bonuses and benefit of kin amounts as the only proxy for executives' remuneration may not provide us a more meaningful insight of Sharebased payments of total remunerations such as Executive Share Option Scheme (ESOS) or Employee Stock Option (ESO). Moreover, this study did not specify whether the non-executives directors are independent or nonindependent. In order to achieve better and accurate results for future research, suggestions are proposed. The investigation of total remuneration can be broken into several components such as salaries, benefit-in-kind, and other kinds of Share-based payments due to studying the sensitivity of executives' remuneration components to independents variables. Lastly, besides these independent variables, there are some other governance variables that might affect executives' remuneration which are not included in this research, but they can be studied in further research. For example, the remuneration committee, CEO tenure, ownership structure. Studying the mentioned variables will have a better understanding on the factors that will affect executives' remuneration.

\section{NOTES}

1. Recommendation 2.3 of MCCG (2012) suggests that the BOD should establish transparent and formal remuneration procedures and policies to attract and retain directors. The commentary for this recommendation is that fair remuneration is essential to motivate, attract, and retain executives. The remuneration package should be aligned with longterm aims and strategies of the companies. The board remuneration should reflect the BOD's responsibilities, complexity, and proficiency of the firm's activities. The BOD should establish a remuneration board to fulfil this function; board remuneration procedures and policies should also be disclosed in the firm's annual report.

\section{REFERENCES}

Abdullah, S. N. 2006. Directors' remuneration, firm's performance and corporate governance in Malaysia among distressed companies. Corporate Governance 6(2): 162-174.

Abdullah, W. Z. W., Ismail, S., \& Jamaluddin, N. 2016. The impact of board composition, ownership and CEO duality on audit quality: The Malaysian evidence. Malaysian Accounting Review 7(2): 17-28.

Aggarwal, R. K., \& Samwick, A. A. 1999. Executive compensation, strategic competition, and relative performance evaluation: Theory and evidence. The Journal of Finance 54(6): 1970-1999.

Ahmad, N., \& Aris, Y. B. W. 2015. Does Age of the Firm Determine Capital Structure Decision? Evidence from Malaysian Trading and Service Sector. International Business Management 9(3): 200-207.

Allen, M. P. 1981. Power and privilege in the large corporation: corporate control and managerial compensation. American Journal of Sociology : 1112-1123.

Amin, J., Kamarudin, K., Ismail, W., \& Sarman, S. 2013. What determines directors' remuneration in Malaysia? Innovation, Communication and Engineering, 469-473.

Amin, J. M., Kamarudin, K. A., \& Ismail, W. A. W. 2014. What determines directors' remuneration in Malaysia? Recent trends in Social and Behavioral Science-Lumban Gaol et al. (Eds) : 469-473.

Ang, J. S., Cole, R. A., \& Lin, J. W. 2000. Agency costs and ownership structure. The Journal of Finance 55(1): 81106.

Angbazo, L., \& Narayanan, R. 1997. Top management compensation and the structure of the board of directors in commercial banks. European Finance Review 1(2): 239-259.

Appannan, S., \& Sim, L. W. 2011. A Study on Leading Determinants of Dividend Policy in Malaysia Listed Companies for Food Industry Under Consumer Product Sector. Paper presented at the 2 nd International Conference on Business and Economic Research: 945-976.

Attaway, M. 2000. A study of the relationship between company performance and Executive remuneration. American Business Review 18(1): 77-85.

Banghøj, J., Gabrielsen, G., Petersen, C., \& Plenborg, T. 2010. Determinants of executive compensation in privately held firms. Accounting \& Finance 50(3): 481-510.

Bao, Y. 2013. Executive Compensation, Cash Dividend Policy and Compensation Contracts Design. Collected Essays on Finance and Economics.

Bebchuk, L. A., Cohen, A., \& Spamann, H. 2010. Wages of Failure: Executive Compensation at Bear Stearns and Lehman 2000-2008, The. Yale J. on Reg. 27: 257-282.

Bebchuk, L. A., \& Fried, J. M. 2004. Executive compensation as an agency problem. Journal of Economic Perspective 17(3): 71-92.

Benson, B. W., \& Davidson, W. N. 2010. The relation between stakeholder management, firm value, and CEO compensation: A test of enlightened value maximization. Financial Management 39(3): 929-964.

Bhattacharyya, N., Mawani, A., \& Morrill, C. 2008. Dividend payout and executive compensation: theory and evidence. Accounting \& Finance 48(4): 521-541.

Cadbury, A. 1992. Report of The Committee on The Financial Aspects of Corporate Governance. Vol. 1: Gee

Carter, D. A., Simkins, B. J., \& Simpson, W. G. 2003. Corporate governance, board diversity, and firm value. Financial Review 38(1): 33-53. 
Cheah, K. G., Lim, L. B., \& Yen, W. S. 2012. Executive Director Compensation in Malaysia: A Study of Firms with Substantial Shareholding. OIDA International Journal of Sustainable Development 5(05): 23-30.

Cheung, Y.-L., Stouraitis, A., \& Wong, A. W. 2005. Ownership concentration and executive compensation in closely held firms: Evidence from Hong Kong. Journal of Empirical Finance 12(4): 511-532.

Chowdhury, D. 2012. Incentives, Control and Development: Governance in Private and Public Sector with Special Reference to Bangladesh: Dhaka viswavidyalay prakashana samstha University of Dhaka.

Conyon, M. J. 1997. Corporate governance and executive compensation. International Journal of Industrial Organization 15(4): 493-509.

Conyon, M. J., Core, J. E., \& Guay, W. R. 2010. Are US CEOs paid more than UK CEOs? Inferences from risk-adjusted pay. Review of Financial Studies 24(2): 1-50.

Conyon, M. J., \& Peck, S. I. 1998. Board control, remuneration committees, and top management compensation. Academy of Management Journal 41(2): 146-157.

Core, J. E., Holthausen, R. W., \& Larcker, D. F. 1999. Corporate governance, chief executive officer compensation, and firm performance. Journal of Financial Economics 51(3): 371-406.

Council, F. R. 2012. The UK Corporate Governance Code. London, September.

Croci, E., Gonenc, H., \& Ozkan, N. 2012. CEO compensation, family control, and institutional investors in continental Europe. Journal of Banking \& Finance 36(12): 3318-3335.

DeAngelo, H., \& DeAngelo, L. 1985. Managerial ownership of voting rights: A study of public corporations with dual classes of common stock. Journal of Financial Economics 14(1): 33-69.

Dogan, E., \& Smyth, R. 2002. Board remuneration, company performance, and ownership concentration: Evidence from publicly listed Malaysian companies. ASEAN Economic Bulletin 19(3): 319-347.

El-Jor, N. K. 2017. Agency Problem Types From a Corporate Governance Perspective. In Entrepreneurship and Business Innovation in the Middle East (pp. 175-191): IGI Global.

Elsayed, N., \& Elbardan, H. 2018. Investigating the associations between executive compensation and firm performance: Agency theory or tournament theory. Journal of Applied Accounting Research 19(2): 245-270.

Fahlenbrach, R., \& Stulz, R. M. 2011. Bank CEO incentives and the credit crisis. Journal of Financial Economics 99(1): 11-26.

Fama, E. F., \& Jensen, M. C. 1983. Agency problems and residual claims. Journal of Law and Economics: 327-349.

Fernandes, N., Ferreira, M. A., Matos, P., \& Murphy, K. J. 2013. Are US CEOs paid more? New international evidence. Review of Financial Studies 26(2): 323-367.

Finkelstein, S., \& D'aveni, R. A. 1994. CEO duality as a double-edged sword: How boards of directors balance entrenchment avoidance and unity of command. Academy of Management Journal 37(5): 1079-1108.

Fleming, G., Heaney, R., \& McCosker, R. 2005. Agency costs and ownership structure in Australia. Pacific-Basin Finance Journal 13(1): 29-52.

Ghazali, Z., \& Taib, F. M. 2015. It Pays to Be an Executive in Malaysia. The Journal of Developing Areas 49(5): 225-237.
Goh, L., \& Gupta, A. 2016. Remuneration of non-executive directors: Evidence from the UK. The British Accounting Review 48(3): 379-399.

Gurajati, D. 2003. Basic Econometrics. New York: McGraw Hill.

Hamsawi, R. 2011. Top Ringgit for Head Honchos. Accessed from https://www.highbeam.com

Hassan, S., Christopher, T., \& Evans, R. 2003. Directors' remuneration and firm performance: Malaysian evidence. Malaysian Accounting Review 2(1): 57-67.

Healy, P. M. 1985. The effect of bonus schemes on accounting decisions. Journal of Accounting and Economics, 7(1): 85107.

Hill, C. W., \& Jones, T. M. 1992. Stakeholder-agency theory. Journal of Management Studies 29(2): 131-154.

Holderness, C. G., \& Sheehan, D. P. 1988. The role of majority shareholders in publicly held corporations: An exploratory analysis. Journal of Financial Economics 20 : 317-346.

Ibrahim, M. K., Ibrahim, N., Ismal, W., Adibah, W., \& Kamarudin, K. A. 2005. Determinants of directors' remuneration: Malaysian evidence 1998-2001. Social and Management Research Journal 2(1): 48-60.

brahim, N. A., Zin, N. N. M., Kassim, A. A. M., \& Tamsir, F. 2019. How Does Directors' Remuneration and Board Structure Impact on Firm Performance in Malaysia Telecommunication Industry? European Journal of Business and Management Research 4(4).

Ismail, S. B., Yabai, N. V., \& Hahn, L. J. 2014. Relationship between CEO Pay and Firm Performance: Evidences from Malaysia Listed Firms. Journal of Economics and Finance 3(6):14-31.

Iyengar, R. R. J., Williams, H. J., \& Zampelli, E. M. 2005. Sensitivity of executive pay to accounting performance measures in all-equity firms. Accounting \& Finance 45(4): 577-595.

Jaafar, M. Y., Nawawi, A., Salin, P., \& Azlin, A. S. 2014. Directors' Remuneration Disclosure and Firm Characteristics-Malaysian Evidence. International Journal of Economics \& Management 8(2): 269-293.

Jaafar, S. B., \& James, K. 2013. Determinant of Director Remuneration in Malaysia Public Listed Companies. International Journal of Trade, Economics and Finance 4(6): 353-357.

Jaafar, S. B., \& James, K. 2014. Director Remuneration Pay: Trends During and After the Financial Crisis of 2007 to 2009. Australasian Accounting Business \& Finance Journal 8(3): 175-191.

Jaafar, S. B., James, K., \& Wahab, E. A. A. 2012. Remuneration Committee and Director Remuneration in Family-Owned Companies: Evidence from Malaysia. International Review of Business Research Papers 8(7): 17-38.

Jaafar, S. B., Wahab, E. A. A., \& James, K. 2012. Director remuneration and performance in Malaysia family firms: an expropriation matter? World Review of Business Research 2(4): 204-222.

Jeelinek, K., \& Stuerke, P. S. 2009. The non-linear relation between agency costs and managerial equity ownership. International Journal of Managerial Finance 5(2): 156178.

Jensen, M. C., \& Meckling, W. H. 1976. Theory of the firm: managerial behavior, agency costs, and ownership structure. Journal of Financial Economics 3(4): 78-79. 
Jensen, M. C., \& Murphy, K. J. 1990. Performance pay and top-management incentives. Journal of Political Economy 98(2): 225-264.

Jiraporn, P., Miller, G. A., Yoon, S. S., \& Kim, Y. S. 2008. Is earnings management opportunistic or beneficial? An agency theory perspective. International Review of Financial Analysis 17(3): 622-634.

Johl, S. K., Kaur, S., \& Cooper, B. J. 2015. Board characteristics and firm performance: Evidence from Malaysian public listed firms. Journal of Economics, Business and Management 3(2): 239-243.

Jong, L. 2018. Executive Remuneration of Listed Family Companies in Malaysia. Curtin University.

Jong, L., \& Ho, P.-L. 2019. Family directors, independent directors, remuneration committee and executive remuneration in Malaysian listed family firms. Asian Review of Accounting 28(1): 24-47.

Kahle, \& Kathleen. 2002. When a buyback isn't a buyback: Open-market repurchases and employee options. Journal of Financial Economics 63: 235-261.

Kang, K. H., Lee, S., \& Huh, C. 2010. Impacts of positive and negative corporate social responsibility activities on company performance in the hospitality industry. International Journal of Hospitality Management 29(1): 72-82.

Kaur, G., \& Rahim, N. 2007. Who gets the big money. Malaysian Business 1: 16-17.

Kirkpatrick, G. 2009. Corporate Governance Lessons from the Financial Crisis (Vol. 1): OECD Financial Market Trends.

Laing, D., \& Weir, C. M. 1999. Governance structures, size and corporate performance in UK firms. Management Decision 37(5): 457-464.

Lee, S.-P., \& Chen, H.-J. 2011. Corporate governance and firm value as determinants of CEO compensation in Taiwan: 2SLS for panel data model. Management Research Review 34(3): 252-265.

Lewellen, W., Loderer, C., \& Martin, K. 1987. Executive compensation and executive incentive problems: An empirical analysis. Journal of Accounting and Economics 9(3): 287-310.

Lim, B. L., \& Yen, S. H. 2017. Agency problem and expropriation of minority shareholders. Malaysian Journal of Economic Studies 48(1): 37-59.

Lin, D., \& Lin, L. 2014. The interplay between director compensation and CEO compensation. The International Journal of Business and Finance Research 8(2): 11-26.

Malak, S. S. D. A. 2015. The Determinants of Disclosure of Individual Executive Director's Remuneration: A Malaysian Perspective. Procedia-Social and Behavioral Sciences 172: 666-673.

Mat Nor, F., \& Sulong, Z. 2007. The interaction effect of ownership structure and board governance on dividends: Evidence from Malaysian listed firms. Capital Market Review 15(1 and 2): 73-101.

McConaughy, D. L. 2000. Family CEO vs. Non-family CEOs in the familycontrolled firm: An examination of the level and sensitivity of pay to performance. Family Business Review 13(2): 121-131.

McKnight, P. J., \& Weir, C. 2009. Agency costs, corporate governance mechanisms and ownership structure in large UK publicly quoted companies: A panel data analysis. The Quarterly Review of Economics and Finance 49(2): 139-158.
Mehran, H. 1995. Executive compensation structure, ownership, and firm performance. Journal of Financial Economics 38(2): 163-184.

Mengistae, T., \& Colin Xu, L. 2004. Agency theory and executive compensation: The case of Chinese state-owned enterprises. Journal of labor Economics 22(3): 615-637.

Miller, J. L. 2002. The board as a monitor of organizational activity: The applicability of agency theory to nonprofit boards. Nonprofit Management and Leadership 12(4): 429-450.

Murphy, K. J. 1999. Executive compensation. Handbook of Labor Economics 3: 2485-2563.

Nahar Abdullah, S. 2006. Directors' remuneration, firm's performance and corporate governance in Malaysia among distressed companies. Corporate Governance: The International Journal of Business in Society 6(2): 162-174.

Neter, J., Wasserman, W., \& Kutner, M. 1983. Applied Linear Regression Models, Homewood, IL: Richard D. Irwin Inc.

Ntim, C. G., Lindop, S., Osei, K. A., \& Thomas, D. A. 2013. Executive Compensation, Corporate Governance and Corporate Performance: A Simultaneous Equation Approach. Managerial and Decision Economics 36(2): 67-96.

Nurim, Y., Sunardi, S., \& Raharti, R. 2017. The Type I Versus Type II Agency Conflict on Earnings Management. Jurnal Dinamika Manajemen 8(1): 44-58.

Ozkan, N. 2007. Do corporate governance mechanisms influence CEO compensation? An empirical investigation of UK companies. Journal of Multinational Financial Management 17(5): 349-364.

Panda, B., \& Leepsa, N. 2017. Agency theory: Review of theory and evidence on problems and perspectives. Indian Journal of Corporate Governance 10(1): 74-95.

Pearce, J. A., \& Zahra, S. A. 1991. The relative power of CEOs and boards of directors: Associations with corporate performance. Strategic Management Journal 12(2): 135153.

Ratnawati, V., Abdul-Hamid, M. A., \& Popoola, O. M. J. 2016. The influence of agency conflict types I and II on earnings management. International Journal of Economics and Financial Issues 6(4): 126-132.

Remuneration, S. G. o. D., \& Greenbury, S. R. 1995. Directors' remuneration: Gee London.

Saleh, N. M., Iskandar, T. M., \& Rahmat, M. M. 2005. Earnings management and board characteristics: Evidence from Malaysia. Jurnal Pengurusan 24(4): 77-103.

Salim, B., \& Wan-Hussin, W. N. 2009. Remuneration committee, ownership structure and pay-for-performance: evidence from Malaysia. Available at SSRN $1515166: 1-42$.

Singh, M., \& Davidson, W. N. 2003. Agency costs, ownership structure and corporate governance mechanisms. Journal of Banking \& Finance 27(5): 793-816.

Sridharan, U. V. 1996. CEO influence and executive compensation. Financial Review 31(1): 51-66.

Stulz, R. 1988. Managerial control of voting rights: Financing policies and the market for corporate control. Journal of Financial Economics 20: 25-54.

Taufil-Mohd, K. N., Md-Rus, R., \& Musallam, S. R. 2013. The effect of ownership structure on firm performance in Malaysia. International Journal of Finance and Accounting 2(2): 75-81. 
Ueng, C. J., Wells, D. W. \& Lilly, J. D. 2000. CEO influences and executive compensation: large firms vs. small firms. Managerial Finance 26(8): 3-12.

Uyar, A. 2009. The relationship of cash conversion cycle with firm size and profitability: an empirical investigation in Turkey. International Research Journal of Finance and Economics 24(2): 186-193.

Verbeek, M. 2008. A Guide to Modern Econometrics. John Wiley \& Sons.

Vethanayagam, J., Yahya, S., \& Haron, H. 2006. Independent non-executive directors, managerial ownership and firm performance in Malaysian public listed companies. Paper presented at the Proceeding Symposium on Accountability, Governance and Performance.

Vicknes, S. 2003. Top earners in Malaysia. Accountants Today 16(10): 12-15.

Werner, S., Tosi, H. L., \& Gomez-Mejia, L. 2005. Organizational governance and employee pay: How ownership structure affects the firm's compensation strategy. Strategic Management Journal 26(4): 377-384.

Wooi, H. C., \& Ming, M. T. C. 2009. Directors' PayPerformance: A Study on Malaysian Government Linked Companies. Centre for Policy Research and International Studies: 1-19.

Yatim, P. 2013. Directors' Remuneration and Corporate Governance in Malaysia. Paper presented at the The 7th
Asia Pacific Interdisciplinary Research in Accounting Conference.

Yermack, D. 1996. Higher market valuation of companies with a small board of directors. Journal of Financial Economics 40(2): 185-211.

Zhou, X. 2000. CEO pay, firm size, and corporate performance: evidence from Canada. Canadian Journal of Economics/ Revue Canadienne d'économique 33(1): 213-251.

Zulkarnain, M. 2007. Towards Better Corporate Governance and Transparency. Paper presented at the Conference on Managing Knowledge in the Borderless World, Selangor, Malaysia, February.

Maziar Ghasemi

Putra Business School

Universiti Putra Malaysia

43400 UPM Serdang Selangor

MALAYSIA

E-mail : maziarghasemi@gmail.com

Nazrul Hisyam Ab Razak

Faculty of Economics and Management

Universiti Putra Malysia

43400 UPM Serdang

MALAYSIA

E-mail: nazrul@upm.edu.my 